\title{
Czy Teoria Aktora-Sieci daje narzędzia do ekokrytyki?
}

Krzysztof Abriszewski

TEKSTY DRUGIE 2018, NR 2, S. 369-391

DOI: $10.18318 /$ td.2018.2.23

Droblemy o charakterze środowiskowym, które uderzają w nas na co dzień, jak choćby smog w miastach, informacje o niebezpiecznym stężeniu ftalanów w zabawkach czy w żywności i wiele innych, uzmysławiają nam wiele problemów, przed którymi stoi dziś teoria w humanistyce i naukach społecznych: przede wszystkim, jaki słownik, czy słowniki, jakie narzędzia teoretyczne i ujęcia mogą nam najlepiej posłużyć do badania kultury właśnie wobec dzisiejszych problemów środowiskowych? Przyjmijmy, że roboczo - i tylko w takim trybie - zapytamy po prostu, o to, jak badać kulturę w czasie antropocenu? Druga kwestia, ściśle z powyższą związana - jakie narzędzia teoretyczne najlepiej posłużą do rozszerzenia powyższego o moment krytyczny? Jak w ogóle postrzegać dziś pracę krytyczną i teorię krytyczną? Jakie powinny być jej zadania, jakie środki, jakie przymierza? Lokując się w tym olbrzymim tyglu problemów współczesności, chciałbym bliżej i w trybie krytycznym przyjrzeć się tylko jednemu, ale za to bardzo wpływowemu

\section{Krzysztof}

Abriszewski - dr hab., pracownik Instytutu Filozofii Uniwersytetu Mikołaja Kopernika w Toruniu, członek Komitetu Naukoznawstwa PAN. Ostatnio opublikował Kulturowe funkcje filozofowania (2013) oraz jako współautor (wraz z Andrzejem W. Nowakiem i Michałem Wróblewskim) Czyje lęki? Czyja Nauka? Struktury wiedzy wobec kontrowersji naukowo-społecznych (2016). Kontakt: krzabr@umk.pl 
podejściu i zapytać, czy rozwijane przez lata stanowisko Bruno Latoura wraz z jego wersją Teorii Aktora-Sieci (ANT), której przecież zawsze był jednym $\mathrm{z}$ wiodących reprezentantów, nadaje się do ekokrytyki? A jeśli tak, to w jakim wymiarze? Jeśli zaś nie, to dlaczego?

Teoria Aktora-Sieci wydaje się na pierwszy rzut oka o tyle dobrą kandydatką do rozważenia jej roli w uwrażliwionym na środowisko badaniu ludzkiego zbiorowego świata, że zalicza się ją do nurtu tzw. płaskich ontologii, które postulują zniesienie wielu tradycyjnych podziałów ontologicznych, jak np. podział na naturę i społeczeństwo. Argumentacja wygląda tutaj w ten sposób, że przyjęcie tego rodzaju ontologicznej dychotomii automatycznie rozdziela zainteresowania poznawcze na dotyczące społeczeństwa i dotyczące przyrody. I konsekwentnie badanie ludzkich spraw systematycznie biorące pod uwagę też sprawy pozaludzkie - non-human - skorzysta ze zniesienia tej opozycji, przynajmniej jej osłabienia. Ale drugą kwestią jest jeszcze praca krytyczna. To, jak toczą się dyskusje wokół zmian klimatycznych, pokazuje, że krytyka jest potrzebna bardziej niż kiedykolwiek. Na potrzeby poniższych wywodów i tylko w tym kontekście, chciałbym więc traktować „ekokrytykę" jako operację krytyczną charakteryzującą się powyższymi dwoma punktami: umożliwienie badania kultury (społeczeństwa, spraw ludzkich etc.) z uwrażliwieniem na kwestie środowiskowe dzięki zmianom w przyjmowanej ontologii oraz oferowanie narzędzi dla pracy krytycznej.

Pytanie o możliwość ekokrytyki w kontekście podejścia Latoura postawię w zasadniczo dwóch ujęciach: po pierwsze, w kontekście napięcia między Latourową tezą, że nigdy nie byliśmy nowocześni a akceptacją przez niego perspektywy antropocenowej; po drugie, przyglądając się sposobowi ujęcia przez Latoura tych problemów w książce Facing Gaia. Wskażę też bardzo krótko współczesne krytyczne ujęcia propozycji Latoura, jakie można znaleźć wśród badaczy kultury i badaczy społecznych piszących o antropocenie. Ponieważ konkluzje raczej wskażą na to, że mimo zainteresowania problemami środowiskowymi, któremu Latour dał wyraz choćby w Polityce natury i przy licznych innych okazjach, nie jest on w stanie wiele zaoferować dyskursowi ekokrytycznemu, zaproponuję pewne przekształcenia niektórych z jego ujęć teoretycznych, które mogą otworzyć drogę dla tego rodzaju pracy krytycznej.

\section{Nowoczesność}

Próbując się zmierzyć z kwestią ujęcia zmian klimatycznych w modelu epoki historycznej, na przykład w formie antropocenu, Latour staje przed jednym 
zasadniczym wyzwaniem teoretycznym: w jaki sposób pogodzić swoją wcześniejszą tezę o tym, że nigdy nie byliśmy nowocześni z akceptacją antropocenu? Autor Nadziei Pandory wydaje się, przynajmniej w pewnej mierze, świadom tego problemu', gdy deklaruje, że antropocen wreszcie będzie stanowić alternatywę dla (teorii) Nowoczesności². Na razie zwróćmy uwagę na pewną paradoksalność tej sytuacji: zarówno wysiłki określenia początku Nowoczesności, jak i początku antropocenu krążą wokół podobnych dat, podobnych zdarzeń, w obu przypadkach mamy próbę wyłuskania charakterystycznych cech określających współczesność jako pewną formację historyczną.

Ruch Latoura, na pozór skuteczny, kieruje się w stronę rozłączenia obu podejść teoretycznych tak, by nie wyglądały na spokrewnione. Francuski badacz chętnie akceptuje geologiczne czy, szerzej - przyrodoznawcze, wyznaczanie specyfiki antropocenu ${ }^{3}$, natomiast teza o tym, że nigdy nie byliśmy nowocześni, ma operować na poziomie świadomościowym ${ }^{4}$ - wydawało nam się, że jesteśmy całkowicie inni niż ci, którzy żyli przed nami (pierwszy wielki podział) i analogicznie odmienni od egzotycznych innych, od "onych" spoza naszego kręgu kulturowego (drugi wielki podział) ${ }^{5}$, ale to były złudzenia naszych wyobrażeń o sobie.

Przypomnę, że schemat leżący u podstaw wyjaśnienia (ryc. 1), a następnie odrzucenia wielkich podziałów przedstawiał dwa zasadnicze poziomy. Poniżej na schemacie znajdowały się ontologicznie płaskie sieci, które namnażały się współcześnie szczególnie intensywnie (operacje translacji), ale w drugim ruchu ulegały one oczyszczeniu tak, że powstawały z nich dwa bieguny: natury i społeczeństwa. Nawiasem mówiąc, do walki z opozycją natura/społeczeństwo Latour powraca w Facing Gaia (19-47). Rzekoma nowoczesność wyłaniała się tam, gdzie wydawało się, że świetnie rozróżniamy, jakie zjawiska są naturalne, a jakie społeczne. Nasi przodkowie nie potrafili tego robić wcale albo przynajmniej tak dobrze robić, więc tu pojawia się pierwszy wielki

1 Zob. np. B. Latour Facing Gaia. Eight Lectures on the New Climactic Regime, trans. C. Porter, Polity Press, Cambridge 2017, s. 26. Korzystałem z ebuka w formie epub, niekiedy numeracja stron w tym formacie (wykazywanych w tekście, a nie w interfejsie urządzenia) różni się nieznacznie od numeracji w wydaniu papierowym.

2 Tamże, s. 144 .

3 Tamże, s. 140-179.

4 Zob. B. Latour Nigdy nie byliśmy nowocześni. Studium z antropologii symetrycznej, przeł. M. Gdula, Oficyna Naukowa, Warszawa 2011.

5 Tamże, s. 139-143. 

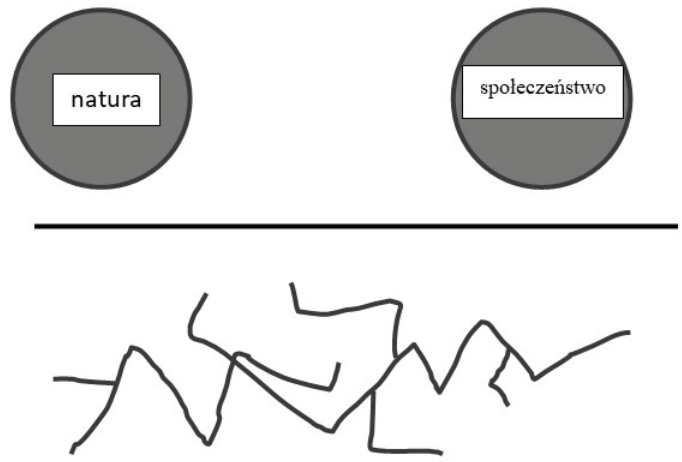

dualistyczna

metafizyka

oczyszczanie

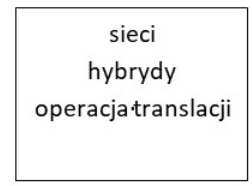

Ryc. 1. Schemat Nowoczesności Latoura przedstawiający poziom operacji translacji wytwarzających sieci-hybrydy (poniżej) oraz po operacji oczyszczania tworzący dwa przeciwstawne bieguny natury i społeczeństwa ${ }^{6}$.

podział. Front modernizacyjny przesuwa się więc wraz ze strzałką czasu, coraz lepiej separując bieguny natury i społeczeństwa od siebie ${ }^{7}$. Tym samym Nowocześni są przekonani o tym, że różnią się zasadniczo od ludzi, którzy żyli w przeszłości, czyli byli „przed-Nowocześni”. Analogicznie rzecz się ma z sytuacją, gdy Nowocześni odkrywają innych im współczesnych, a nie przeszłych, którzy nie rozróżniają w taki sposób, jak oni obu biegunów. Wtedy wytwarza się drugi wielki podział.

Sęk w tym, że niezależnie od autowyobrażeń Nowoczesnych wszędzie działają płaskie sieci wiążące ze sobą rozmaite, odmienne materiały, wszędzie mamy do czynienia z heterogeniczną inżynierią', by posłużyć się określeniem Johna Lawa. Kluczowe jest nie tyle przestrzeganie czystości ontologicznej obu biegunów - sprawy ludzkie z jednej strony, a kwestie natury z drugiej - ile stabilizowanie się wyłaniających ${ }^{9}$ się układów (asamblaży), sieci, sprawczości, podmiotowości etc.

6 Schemat ten przywołuję za: tamże, s. 23, Rysunek 1.

7 Filozoficzny obraz tej powiększającej się separacji Latour przedstawia w tej samej książce: tamże, s. 82-86.

8 J. Law Uwagi na temat teorii aktora-sieci: wytwarzanie ładu, strategia i heterogeniczność, przeł. K. Abriszewski, w: Studia nad nauką i technologiq̨. Wybór tekstów, red. E. Bińczyk, A. Derra, Wydawnictwo Naukowe UMK, Toruń 2014, s. 218.

9 Tamże, s. 223-226. Law posługuje się w tym kontekście pojęciem „punktualizacji”, oznaczającym sprowadzenie złożonej sieci relacji do jednego punktu, działa ona wtedy jako jedność, jest stabilna. 
W tym miejscu może się jednak pojawić pierwsza wątpliwość dotycząca tezy o tym, że nigdy nie byliśmy nowocześni. Latour mówi bowiem, że szczególna, przedziwna ślepota Nowoczesnych, ich wyobrażenie o dwóch biegunach, czy, jak mówi Latour, Nowoczesna Konstytucja ${ }^{10}$, wytworzyły warunki dla "niekontrolowanego płodzenia się hybryd"11. To jednakże oznaczałoby, że przynajmniej w jakimś wymiarze nastąpiła jakościowa zmiana wyróżniająca kulturę nowoczesną - udało się jej skonstruować mechanizm przyspieszenia ilości i tempa zmian, czy też liczby wprowadzanych do zbiorowego świata innowacji, poprzez umiejętne wyłączenie mechanizmów kontrolnych. Przypomnę, że te ostatnie polegają na tym, że planowanie i ocenianie zmiany w zbiorowym świecie oddelegowano wyłącznie do bieguna kultury/społeczeństwa. Chodzi tu np. o rozmaite procedury polityczne. A jednocześnie, zasadniczym obszarem generowania innowacji w niewyobrażalnych ilościach stała się nauka, głównie nauki przyrodnicze, które jednak zostały przypisane do bieguna (ahistorycznej) natury jako poznawanie czystych faktów. Toteż głównym naszym problemem są niekontrolowane zmiany. To zaś, co Nowocześni postrzegają jako niedostatek poznawczy u nie-Nowoczesnych, w istocie oznacza obecność tychże mechanizmów kontrolnych, które spowalniają proces wprowadzania innowacji do zbiorowości.

W tym duchu należy postrzegać Latourowski projekt zarysowany w książce Polityka natury ${ }^{12}$, której centralną pozycję zajmuje schemat przedstawiający trajektorię zmiany w zbiorowości wychodzącej od momentu propozycji nowego aktora, gdy innowacja "puka do bram” zbiorowości, przechodzi następnie cztery etapy (w wersji Nowoczesnej skrócone do dwóch), a na końcu albo zostaje wchłonięta przez zbiorowość, albo odrzucona jako byt eksternalizowany ${ }^{13}$.

I znów, zwróćmy uwagę, że jednak Nowoczesność zostaje jakościowo odróżniona, poprzez patologiczny mechanizm przyspieszania procesu zmiany i omijania dwóch kluczowych etapów dyskusji (konsultacji oraz hierarchizacji) i umieszczania tego, co nowe od razu w porządku bytów.

B. Latour Nigdy nie byliśmy nowocześni, s. 25-72.

Tamże, s. 9-11, zob. także 61-65.

B. Latour Polityka natury. Nauki wkraczają do demokracji, przeł. A. Czarnacka, Wydawnictwo Krytyki Politycznej, Warszawa 2009.

Tamże, np. s. 176. Jednakże w różnych modyfikacjach schemat ten przewija się przez całą książkę. 
Mówiąc językiem nie-Latourowym można by poczynić takie podsumowanie: Nowoczesność zaistniała jedynie na poziomie ideologicznym wytwarzając złudzenie dwóch przeciwstawnych biegunów natury i społeczeństwa. Zmistyfikowała ona jednak ukrytą "głębiej” rzeczywistość płaskiej ontologii sieci i hybryd. Mistyfikacja ta zdynamizowała procesy hybrydyzacji. Na tym głębokim poziomie nigdy nowocześni nie byliśmy, bo jakościowo zachodzące tam procesy nie różnią się niczym od tego, co dzieje się (lub działo) w zbiorowościach nienowoczesnych. Zaś poziom ideologicznej mistyfikacji jest przedmiotem demistyfikującego wywodu Latoura w książce Nigdy nie byliśmy nowocześni.

Jednakże kontynuacja, którą odnajdujemy w Polityce natury, dodatkowo jeszcze sprawę pokomplikowała, ponieważ z tezy o krótkim podpięciu patologicznej nowoczesnej zmiany wynika, że jednak mistyfikujący poziom ideologiczny wpłynął zwrotnie na kształt procesów głębokich. To oczywiście utrudnia podtrzymywanie przekonania, że nigdy nie byliśmy nowocześni. Latour jednak nie wraca do tych kwestii, a przynajmniej nie w taki sposób.

Celowo w dwóch powyższych akapitach posługuję się kategoriami, których Latour unika jak ognia, po to, aby pokazać, że operacje teoretyczne, które on wykonuje, wcale nie odbiegają zasadniczo od znanego repertuaru teorii krytycznych.

Wreszcie wraz z Facing Gaia pojawia się kolejne zagrożenie. Zaakceptowanie tezy o początku antropocenu ${ }^{14}$ oznacza szereg zbieżności z licznymi teoriami nowoczesności. I znów strategia Latoura polega na unikach - nie porównuje, nie zestawia ani nie łączy tezy o antropocenie z żadnymi teoriami przedstawiającymi narodziny nowoczesności. Wchodzi głębiej w opis tego, jak geologowie dyskutują nad kwestią ustalenia, czy przyjąć nową epokę geologiczną i zamknąć Holocen, czy też nie ${ }^{15}$, ale całkowicie pomija prostą konsekwencję zasadniczej tezy o antropocenie. Skoro „człowiek” stał się siłą telluryczną, to automatycznie pojawia się szereg pytań: jaki człowiek? za sprawą jakich procesów? kiedy te procesy się zaczęły? czy ktoś nimi steruje? dlaczego były w stanie zachodzić tak długo mimo konieczności nakładów olbrzymich środków i energii? itd. Słowem, najbardziej elementarny trening z zakresu nauk społecznych czy humanistycznych skłania do przełożenia tezy o antropocenie (np. wyliczeń stężenia dwutlenku węgla w atmosferze) na kategorie społeczne i kulturowe, do pytania o rolę i przebieg industrializacji 
(skoro nawet Paul Crutzen sugeruje, by jako umowny początek przyjąć opatentowanie silnika parowego ${ }^{16}$, o relacje władzy, a wraz z nimi, otwierając wiek XIX, o rolę imperiów i imperializmu.

Czyni to oczywiście wiele autorek i autorów, posuwając się w bardzo różne strony. Być może instruktywne byłoby tutaj przyjrzenie się etykietkom proponowanym jako alternatywa dla krytycznie analizowanego „antropocenu", któremu zarzuca się mylące ujednolicenie rozmaitych ludzi w jednym zbiorczym „człowieku”-, ,anthroposie”, naturalizowanie technokratycznych rozwiązań problemów związanych ze zmianą klimatyczną, maskowanie destrukcyjnych relacji władzy i inne ${ }^{17}$.

Toteż spoglądając z perspektywy humanistycznej (a nie geologicznej), „antropocen” to nic innego jak nowe określenie na Nowoczesność. Jego zaletą jest wydobycie na plan pierwszy problemów ekologicznych, które procesy modernizacyjne spowodowały, ale wadą skrzętne ukrycie całego kontekstu politycznego. Stąd nie dziwi wcale sięganie wprost do rozmaitych narracji o Nowoczesności. Oczywiście, narracja antropocenowa kłóci się z optymistycznymi podejściami teoriomodernizacyjnymi, ale częściowo współgra swym minorowym obrazem z podejściami krytycznymi (jak np. teorią kapitalistycznego systemu-świata Wallersteina w wersji rozwijanej przez Jasona Moore'a $\left.{ }^{18}\right)$, które jednak biją ją na głowę pod względem właśnie zdolności do operacji krytycznych, co być może najlepiej pokazuje książka The Shock of Anthropocene ze swoimi krokami krytycznymi uzupełnionymi o alternatywne narracje $\mathrm{e}^{19}$.

Wniosek niestety jest taki, że Teoria Aktora-Sieci zamaskowała swoje ruchy wywiedzione z tradycji krytycznej takie, jak zderzenie powierzchnia/głębia, ujawnienie głębokiej prawdy, ideologiczna demistyfikacja, opis działania ideologii. Latour postawił na efektowną tezę (kontekstem wtedy były spory wokół ponowoczesności), w której choć pojawia się bardzo cenne

16 Ch. Bonneuil, J.-B. Fressoz The Shock of the Anthropocene. The Earth, History and Us, trans. D. Fernbach, Verso, London-New York 2017, s. 3 i s. 50.

17 Zob. tamże, s. 47-98. Zob. także przenikliwą krytykę Jasona W. Moore'a: tegoż Capitalism in the Web of Life. Ecology and the Accumulation of Capital, Verso, London-New York 2015, np. s. 169-192. Warto jednak wyłuskać argumenty krytyczne pojawiające się w różnych miejscach całej książki.

J.W. Moore Capitalism in the Web of Life.

19 Ch. Bonneuil, J.-B. Fressoz The Shock of Anthropocene, część krytyczna: s. 3-98, alternatywne narracje: s. 99-287. 
rozpoznanie dokonane dzięki przyjętej płaskiej ontologii, to ona sama, nieprzepracowana, przegrywa z kretesem w obliczu tezy o antropocenie. Można bowiem postawić naiwne pytanie: skoro nigdy nie byliśmy nowocześni, to jak nam się udało wejść w antropocen?

Pomyłka teoretyczna, którą Latour popełnił dotyczyła roli, jaką przypisał biegunom natury i kultury, a właściwie jej braku, ale do tego wątku powrócimy nieco dalej.

\section{Krytyczne ujęcia stanowiska Latoura}

Warto chociaż wyrywkowo zaznajomić się z ujęciami krytycznymi w stosunku do propozycji Latoura. Nie jest niczym zaskakującym, że od samego swojego początku ANT była uwikłana w dyskusje, poddawana krytyce, m.in. za swą niewrażliwość polityczną ${ }^{20}$, toteż nie sposób nie odnieść wrażenia, że przynajmniej pewien zakres dzisiejszych zarzutów podąża tym samym torem co dawniejsze argumenty, punktując to, co nie zostało naprawione albo zostało naprawione nie dość dobrze.

Głos krytyczny odnajdujemy w książce The Progress of This Storm Andreasa Malma ${ }^{21}$, którego podejście można streścić następująco: tylko filozoficzny realizm daje nam narzędzia do wiarygodnego mówienia o klimacie i jego związkach z ludzką działalnością. Częścią tego realistycznego nastawienia jest przyjęcie silnej ontologicznej dychotomii natura - społeczeństwo. Stanowisko to powraca na różne sposoby w całej książce, np. w rozdziale pierwszym, w którym Malm prowadzi dyskusję z konstrukcjonizmem (constructionism), w tym konstrukcjonizmem społecznym ${ }^{22}$, czy też w momencie podsumowania dyskusji z Latourowskim obrazem Gai, gdzie autor proponuje

20 Literatura w tym zakresie jest olbrzymia. Przykładowe teksty podejmujące z ANT dyskusję z odniesieniem do polityki, różne tematycznie i czasowo: H. Radder Normative Reflexions on Constructivist Approaches to Science and Technology, "Social Studies of Science” 1992 Vol. 22; A.P. Rudy, B.J. Gareau Actor-Network Theory, Marxist Economics and Marxist Political Ecology, "Capitalism Nature Socialism" 2005 Vol. 16 No. 4; Th. Berker The Politics of 'Actor-Network Theory'. What Can 'Actor-Network Theory' Do to Make Buildings More Energy Efficient?, "Science, Technology \& Innovation Studies" 2006 Special Issue 1; J. Söderberg, A. Netzén When all that is theory melts into (hot) air: Contrasts and parallels between actor network theory, autonomist Marxism, and open Marxism, "Ephemera” 2010 Vol. 10 (2). 
własne rozwinięcie tezy realistycznej w odniesieniu do klimatu w postaci 10 tez, co nazywa zresztą „klimatycznym realizmem”23.

W rozdziale On Unicorns and Baboons: For Climate Realism ${ }^{24}$ Malm czyta uważnie prace Latoura, wskazując na zagnieżdżone w nich sprzeczności. Jego zarzuty można sprowadzić do dwóch zasadniczych kwestii: przekaz Latoura w kwestii negacjonistów zmiany klimatycznej i roli nauki jest niejednoznaczny, przez co w istocie wzmacnia tych pierwszych i osłabia wszystkich tych, którzy chcieliby działać, opierając się na tej drugiej ${ }^{25}$. Po drugie, zupełnie nietrafione w tych okolicznościach jest podtrzymywanie przez Latoura tezy, że należy pozbyć się myśli krytycznej.

O ile Malm za tło swojej książki przyjmuje „twardą” opozycję stanowisk wokół problemów środowiskowych: krytyczni badacze/negacjoniści; stanowiska użyteczne/szkodliwe etc., to Christophe Bonneuil i Jean-Baptiste Fressoz w przywoływanej już wyżej książce The Shock of the Anthropocene ${ }^{26}$ toczą spór na bardziej zniuansowanym terenie, obierając za cel pracy krytycznej w pierwszej części swojej książki dominujące narracje o antropocenie ${ }^{27}$.

Ich zarzuty sprowadzają się do uznania, że podejście Latoura daje się wpisać w schemat dominującej narracji o antropocenie. Podziela ono z tym ostatnim schemat przebudzenia ${ }^{28}$ - kiedyś byliśmy nieświadomi tego, co człowiek robi przyrodzie, ale teraz już się przebudziliśmy, a tym samym to druga cecha - Latour reprodukuje w gruncie rzeczy z „niewielką modyfikacją"Wielki Podział (na przednowoczesnych i nowoczesnych) ${ }^{29}$.

Niebezpieczeństwo związane ze schematem niewiedzy/przebudzenia oraz wielkiego podziału - argumentują autorzy - wiąże się nie tylko z wymazaniem historii refleksji środowiskowej, ale też z tym, że usunięcie jej w taki sposób powoduje „depolityzację kwestii ekologicznych, a tym samym utrudnia zrozumienie dzisiejszych problemów"30.

Tamże, s. 127-137.

Tamże, s. 119-156.

Zob. analizę wywodu Latoura dokonaną przez Malma, tamże, s. 119-127.

Ch. Bonneuil, J.-B. Fressoz The Shock of the Anthropocene.

Tamże, s. 3-98.

Piszą oni: „dla Bruno Latoura, ludzie stali się czynnikiem geologicznym «mimowolnie»” - tamże, s. 74 .

Tamże, s. 75 .

Tamże, s. 78. 
Trzeci argument odnajdujący u Latoura własności dominującej narracji antropocenowej wskazuje na jej technokratycznośśc ${ }^{31}$. Jej bohaterami są naukowcy-przyrodnicy, problemy mają charakter techniczny, rozwiązania również polegają wyłącznie na wyborze takiej czy innej opcji technicznej. W rezultacie znika tradycyjna humanistyczna narracja krytyczna, problemy na skalę planetarną mają swoich fachowców i tylko oni są w stanie je rozpoznać i podjąć w trybie technicznym, nigdy nie są to problemy polityczne czy społeczne, nie wymagają one pracy krytycznej ani reorganizacji społeczno-politycznej.

W tym miejscu dochodzimy więc ponownie od innej strony do konstatacji, która już się pojawiła - stanowisko Latoura, nawet jeśli nie uznamy go, jak Malm, za wprost szkodliwe, nijak nie oferuje narzędzi krytycznych do radzenia sobie z problemami środowiskowymi. Gorzej, nawet umiarkowanie krytyczne odczytanie proponowane przez Bonneuila i Fressoza wyraźnie pokazuje, że jest ono problematyczne w takim sensie, o jakim mówiłem wyżej. Jako teoria nie zwraca naszej uwagi na to, co trzeba, a więcej nawet, odwraca ją w zupełnie inną stronę: od społeczno-politycznej krytyki problemów środowiskowych w stronę wysoce problematycznych ujęć technokratycznych.

\section{Dwóch Jamesów i Gaia, czyli kto podąża za aktorami?}

Próba określenia potencjału krytycznego teorii przez jej analizę i interpretację jest oczywiście normalną formą pracy teoretycznej. Ale znajdujemy się w o tyle korzystnej sytuacji, że możemy bezpośrednio zestawić sposób prowadzenia wywodu przez Latoura na temat interesujących nas zagadnień $\mathrm{z}$ analogicznym momentem w wywodach Christophe'a Bonneuila i Jeana-Baptiste'a Fressoza w The Shock of Anthropocene i je porównać. W innym miejscu argumentowałem, że książka ta jest przede wszystkim gruntownie przemyślaną pracą krytyczną poprowadzoną na kilku poziomach, oferuje bowiem nie tylko krytykę w sensie wyszukania słabości w materiale poddanym analizie i ich wypunktowania, ale przedstawia też kilka alternatywnych i dobrze udokumentowanych narracji ${ }^{32}$. Przeczytajmy dwa dłuższe fragmenty dotyczące postaci Jamesa Lovelocka, twórcy koncepcji Gai, która - jak podpowiada już sam tytuł książki Latoura - stanowi centralną kategorię jego

Zob. tamże, s. 79.

Przygotowana przeze mnie recenzja tej książki złożona do „Prac Kulturoznawczych”. 
nowej propozycji. Najpierw Latour w swoim charakterystycznym gawędziarskim stylu:

Była jesień 1965 roku, gdy w Jet Propulsion Laboratory w Pasadenie, w gabinetach instytutu zajmującego się życiem pozaziemskim, James Lovelock, cokolwiek ekscentryczny inżynier i fizjolog - Anglicy ciągle określają go jako indywidualistę - napisał wraz z Dian Hitchcock (filozofką zatrudnioną w NASA) artykuł na temat możliwości wykrycia życia na Marsie. Oboje autorów peszyło nieco przyznawanie się przed kolegami zajętymi tworzeniem złożonej i kosztownej maszynerii na misje Voyagera, a później Vikinga, którą planowano osadzić na powierzchni Marsa za pomocą gigantycznych rakiet, że aby odpowiedzieć na to pytanie, najlepszym rozwiązaniem będzie pozostać tam gdzie są, w Pasadenie! Powinno ich usatysfakcjonować, mówili autorzy, wycelowanie w czerwoną planetę skromnego instrumentu zaprojektowanego w celu określenia, czy atmosfera znajduje się w stanie chemicznej równowagi, czy też nie i uzyskanie w ten sposób poszukiwanej odpowiedzi. Nie ma potrzeby, by wielkim kosztem lecieć, aby dowieść rzeczy oczywistej. Trudno nie dostrzec symetrii między gestem Galileusza i Lovelocka wzniesienia skromnego instrumentu ku niebu, aby poczynić radykalnie przeciwstawne obserwacje. ${ }^{33}$

Zwróćmy przy okazji uwagę, jak Latour między jednym akapitem a drugim gubi aktorów - z dwójki autorów został tylko jeden wykonujący gest unoszenia aparatury. Dalej zaś czytamy:

Podczas gdy Galileusz, wznosząc swe oczy ponad horyzont ku niebu wzmocnił podobieństwo pomiędzy Ziemią i wszystkimi pozostałymi swobodnymi ciałami, Lovelock opuszczając wzrok z Marsa w naszą stronę, w rezultacie zmniejszył podobieństwo pomiędzy wszystkimi innymi planetami a tą osobliwą Ziemią, która należy do nas. Przyjmując 'punkt widzenia znikąd' wykazał, że nie istnieje 'punkt widzenia znikąd'! W swoim małym gabinecie w Pasadenie, niczym ktoś, kto powoli opuszcza dach kabrioletu, aby go ustawić na miejscu. Lovelock sprowadził swego czytelnika na poziom, który ponownie można postrzegać jako świat sublunarny. Nie dlatego, że Ziemi brakowało doskonałości, wręcz przeciwnie; nie 
dlatego, że w swych wnętrznościach kryła Piekło, ale dlatego, że posiadała - ona jedna? - przywilej pozostawania w nierównowadze, co również oznaczało, że w pewien sposób była podatna na zmiany (being corruptible), bądź, by posłużyć się kategorią z poprzedniego wykładu, że była w taki czy inny sposób ożywiona (animated). ${ }^{34}$

Dość zaskakująco jak na weterana Studiów nad Nauką i Techniką otrzymujemy tu niemalże stereotypowy obrazek samotnego naukowca wnoszącego - w akcie przebłysku geniuszu - nową wiedzę do świata. Dlatego właśnie zwróciłem uwagę na moment pozbycia się współautorki między akapitami, Latour nie podaje argumentów, dlaczego jej wkład w dalszych rozważaniach jest pomijalny. Porzuca ją, kreując obraz, któremu wcale nie jest daleko od takich popkulturowych wyobrażeń jak Dexter z kreskówki dla dzieci (Laboratorium Dextera) czy Rick z kreskówki dla dorosłych (Rick and Morty) - samotnego naukowca w białym kitlu, który mocą wyobraźni buduje urządzenie, robiące "ping" i stwarzające coś nowego.

Zobaczmy teraz jak w zasadzie te same fakty ujęli autorzy książki The Shock of the Anthropocene:

Ze swej strony James Lovelock opierał się na tej ambiwalencji między maszyną a organizmem [tworząc] swą słynną „hipotezę Gai” w 1974 roku. Uczestnicząc w latach '6o w projekcie NASA mającym na celu określenie kryteriów, dzięki którym możliwe stałoby się wykrycie obecności życia na innych planetach, zastanawiał się co wyjaśniałoby możliwość tak długiego zasiedlania (habitability) planety przez żywe organizmy, jak w przypadku Ziemi. Lovelock sformułował hipotezę, że możliwość zasiedlenia również była rezultatem działań żywych istot, działających na rzecz utrzymania warunków korzystnych dla życia. Błękitne algi bądź 'cyjanobakterie', które pojawiły się ponad 3 miliardy lat temu w istocie zmieniły losy Ziemi. ${ }^{35}$

Tutaj autorzy przywołują szereg technicznych szczegółów, które choć interesujące nie są istotne dla naszych rozważań. Ważne zaś jest podsumowanie, które znajdujemy w następnym akapicie:

Tamże, s. 99-100. 
Jeśli Lovelock często kojarzy się z New Age'owskimi mądrościami oraz teleologicznym wydźwiękiem swej teorii, to [należy pamiętać], że w rzeczywistości był on czystym wytworem kompleksu naukowo-militarno-przemysłowego okresu Zimnej Wojny. Po współpracy z NASA, pracował dla CIA w czasie Wojny w Wietnamie nad wykrywaniem obecności ludzi ukrytych w lesie. Jego postdemokratyczna koncepcja planetarnego rządu, apologia energii nuklearnej (nuclear power) oraz systemowe podejście do planety jako samoregulującego się systemu stanowią dziedzictwo perspektywy na świat wywodzącej się z II Wojny Światowej i Zimnej Wojny ${ }^{36}$.

I tutaj widać, jak ścieżki obu wywodów się rozchodzą. Latour w dalszej części rozdziału o Gai rozwija wątek zbieżności między Lovelockiem i Galileuszem oraz dokonuje całkiem tradycyjnej interpretacji prac tego pierwszego, która ma wyjaśnić nieporozumienia wynikające z powierzchowności lektury ${ }^{37}$. Z kolei Bonneuil i Fressoz znacznie szerzej kreślą zimnowojenny kontekst ${ }^{38}$ wskazując jego rolę w pracach jeszcze innych bohaterów i uczestników dyskusji na temat antropocenu. Przykładowo Paul Crutzen powszechnie uznawany za autora tego określenia brał udział w programie badań opracowujących scenariusze nuklearnej zimy możliwej w wyniku wojny nuklearnej ${ }^{39}$.

Nie sposób więc w tym kontekście nie zapytać: kto podąża za aktorami? Albo wręcz powtórzyć za Latourem: „kto zapomnina o relacjach władzy?"40. Celowo podkreśliłem klasyczny gest autora Facing Gaia polegający na reinterpretacji historycznego tekstu, bo chcę go zestawić z tym, co robią Bonneuil i Fressoz: podążają za aktorem i pytają o jego sprawczość. Skoro ważnym graczem w interesującym ich i nas kontekście był Lovelock, to zastanówmy się jakiego rodzaju sieć on stanowi, z czego się ona składa, jaka jest jej sprawczość. Okazuje się, że pytanie z zakresu „socjologicznej analizy

36 Tamże, s. 58.

B. Latour Facing Gaia, s. 97-139.

Ch. Bonneuil, J.-B. Fressoz, The Shock of Anthropocene, np. s. 87-96 czy s. 161-167.

Tamże, s. 92. Ciekawe, że i tutaj można zrobić podobne, choć krótsze zestawienie. Latour również wspomina nuklearną zimę (B. Latour Facing Gaia, s. 165), ale ponownie w jego wydaniu jest to intelektualna przygoda naukowców, a nie brutalny element zimnowojennych działań, których nauka była integralną częścią.

40 B. Latour Splatajqc na nowo to, co społeczne. Wprowadzenie do teorii aktora-sieci, przeł. A. Derra, K. Abriszewski, Universitas, Kraków 2010, s. 116. 
procesów myślowych" - czyli czegoś, co Latour robił w swojej pierwszej książce Laboratory Life, napisanej ze Stevem Woolgarem ${ }^{41}$ - prowadzi do prostego stwierdzenia przejścia: myślenie o Ziemi jako o systemie nie zaczęło się u Lovelocka, gdy pisał o Gai, ale było normalną częścią kontekstu jego wcześniejszych prac związanych z rozmaitymi działaniami zimno- i gorącowojennymi, w których Ziemia stanowiła całościowy, jednolity teatr działań i to nie tylko polegających na przemieszczaniu okrętów czy samolotów na duże odległości, ale również takich, w których wykorzystuje się rozmaite nowe technologie do identyfikowania różnorodnych bogactw naturalnych, a następnie ich eksploatowania ${ }^{42}$.

Moglibyśmy uznać, że ruch krytyczny odbywa się właśnie w tym miejscu, ale Bonneuil i Fressoz idą dalej. W późniejszych partiach swojej książki, tworząc alternatywne sposoby opowiadania historii wobec dominującej narracji antropocenowej, zwracają uwagę na kluczową, a przynajmniej niezwykle istotną rolę działań wojennych dla zmian klimatycznych, które usiłuje uchwycić kategoria antropocenu ${ }^{43}$. Czyli, upraszczając, Lovelock, tworząc wizję Gai, czy Crutzen, pisząc o antropocenie, ujmowali w słowa stan świata, do którego wytworzenia wcześniej się przyczynili. Kto zatem zapomniał o relacjach władzy?

Można oczywiście postawić proste pytanie: jak to się stało, że Latourowi udało się ominąć kontekst zatrudnienia Lovelocka i jakiekolwiek czynniki polityczne z tym związane? Jak to się dzieje, że w The Shock of Anthropocene opisany w ramach zimnej wojny wyścig w kosmos u Latoura staje się opowieścią o śmiałych i pomysłowych eksploracjach kosmosu bez odniesienia militarnego czy politycznego?

Łatwo przywołać tutaj argument Latourowski o konieczności porzucenia myślenia krytycznego, ale jak widzieliśmy, oznacza to nawet naruszenie ANT-owych reguł gry (podążaj za aktorami, pytaj o sprawczość). Z drugiej strony, wydaje się, że autor Nadziei Pandory zapomniał o lekcji (lub ją lekceważy) swego wybitnego rodaka:

wielorakie stosunki władzy przecinają, charakteryzują, konstytuują ciało społeczne; nie mogą one istnieć ani funkcjonować bez

B. Latour, S. Woolgar Laboratory Life. The Social Construction of Scientific Facts, Sage Publications, Beverly Hills-London 1979, s. 168-174. 
nieodłącznej produkcji, akumulacji, cyrkulacji, bez funkcjonowania dyskursu prawdziwościowego. ${ }^{44}$

W istocie trywializując Foucaulta, moglibyśmy tutaj powiedzieć, że naukowcy byli niezbędni, by toczyła się zimna wojna, bo dostarczali coraz to nowych narzędzi do jej prowadzenia. Zderzając krytyczny ruch Bonneuila i Fressoza z wywodem Latoura, można go sprowadzić do dwóch prostych kroków: jak naukowcy współtworzyli kontekst zimnej wojny? Jak kontekst zimnej wojny współtworzył naukowców? Latour nie tylko nie zadaje ani jednego, ani drugiego pytania, ale nie śledzi wcale połączeń, czy powiązań - Lovelocka w tym przypadku - o których tak bardzo przypomina krytycznie omawiając figury Globu oraz Atlasa i przeciwstawiając im Gaję pojmowaną jako coś zbudowanego na połączeniach, a nie jako całość składającą się z części ${ }^{45}$.

Dlaczego kontekst zimnej wojny jest tu taki istotny? Bonneuil i Fressoz, ale również Jason Moore, choć w innym zakresie, precyzyjnie wykazują, że kwestia ustalenia faktycznych historycznych procesów i podmiotów zmian stanowi drogę do przeciwdziałania negatywnym zmianom klimatycznym ${ }^{46}$. Problemy zostaną rozwiązane na dobre nie przez wynajdywanie lokalnych rozwiązań technicznych, a przez rozpoznanie problemogennych procesów i interwencję w tym miejscu. Odnosząc to do naszego przykładu ze smogiem: zamknij fabrykę Stanach Zjednoczonych, a zlikwidujesz (albo zmniejszysz) problem smogu tam, ale otwierając ją później w Chinach, przemieścisz go tylko. Całkowite jego rozwiązanie wymaga innego działania.

Widzimy więc, że Latour nie tylko nie daje narzędzi do pracy ekokrytycznej, ale, że sam jest od niej daleki. Foucault słusznie podpowiada, by „wydobyć na jaw i precyzyjniej określić stawkę, o jaką toczy się gra w tym przeciwstawieniu, w tej walce, $\mathrm{w}$ tym buncie, $\mathrm{w}$ tym wystąpieniu różnych odmian wiedzy przeciwko wiedzy zinstytucjonalizowanej i przeciwko efektom władzy dyskursu naukowego"47 . To znaczy, kształt dyskusji wokół antropocenu wyraźnie potwierdza tezę autora Nadzorować i karać, że „efekty władzy dyskursu naukowego" (współ)wytwarzają określony porządek. Latour asyme-

44 M. Foucault Trzeba bronić społeczeństwa. Wykłady w College de France, 1976, przeł. M. Kowalska, KR, Warszawa 1998, s. 34.

Ch. Bonneuil, J.-B. Fressoz The Shock of the Anthropocene, s. 99-287; J.W. Moore Capitalism in the Web of Life, s. 169-220.

47 M. Foucault Trzeba bronić społeczeństwa, s. 25. 
trycznie traktuje jako źródło wiedzy wypowiedzi przyrodoznawców, czyli to, co Bonneuil i Fressoz nazywają „oficjalnym dyskursem antropocenowym” i wypowiedzi badaczy społecznych i humanistów, które zdają się nie mieć dla niego wielkiej wartości, ale czyniąc to, potwierdza porządek, który tenże oficjalny dyskurs (współ)tworzy. Tymczasem krytyczne ujęcie autorów The Shock of Anthropocene oraz ich alternatywne narracje pokazują słabości zarówno oficjalnego dyskursu, jak i jego porządku. Konkluzja jest taka, że Latour oferuje jeszcze mniej możliwości pracy krytycznej niż robi „sama” tradycyjna ANT.

Moglibyśmy tę analizę poprowadzić dalej, przyjrzeć się bacznie, jak Latour posługuje się w kolejnym rozdziale kategorią antropocenu ${ }^{48}$, którą bierze za dobrą monetę. Moglibyśmy zwłaszcza zwrócić uwagę, że jest świadom rozmaitych dobrze rozpoznanych już, problemów: że całościująca kategoria "anthropos" jest nie do obronienia ${ }^{49}$ czy że porządkowanie historii według stadiów jest co najmniej problematyczne ${ }^{50}$, ale nie jest w stanie zaproponować wiarygodnego pozytywnego ujęcia teoretycznego. Dostajemy szereg znanych już z wcześniejszych jego prac teoretycznych posunięć związanych z koniecznością zwracania uwagi na powiązania, pytania o sprawczość, paradoksalności rozmiarów społecznych aktorów, zwodniczości tego, co globalne, konieczności prac całościujących, by jakąś całość uzyskać jako rezultat, ale wszystko to nie składa się na nic nowego. Owszem, otrzymujemy interesującą reinterpretację sfer Sloterdijka w kategoriach Latourowskich, ale oprócz tego i wielu nieistotnych wtrąceń Latour niepotrzebnie bawi się w rozwijanie mitologii Globu i Atlasa jako bohaterów negatywnych. Czy naprawdę w nich tkwi problem? Czy to Atlas wytwarza smog w Chinach lub w Polsce? Koniec końców jednak, gdy sięgniemy do innych ważnych pozycji podejmujących tematykę antropocenu, dochodzimy do sytuacji przypominającej dwóch Jamesów Lovelocków, których widzieliśmy wcześniej. Relacje władzy, dominacji, hegemonii, ustabilizowane struktury władzy, i rola w nich nauki i naukowców, mechanika kompleksu militarno-przemysłowego, interesy, kapitalizm, nic z tego wszystkiego się u autora Nadziei Pandory nie pojawia. Latour nawet nie próbuje zreinterpretować tych kategorii za pomocą swojego słownika. Nie ma więc mowy o ruchu krytycznym.

B. Latour Facing Gaia, s. 140-179.

Ch. Bonneuil, J.-B. Fressoz The Shock of the Anthropocene, s. 65-98. 


\section{Możliwość pracy krytycznej?}

Kończąc część, w której wydobywałem napięcie między zaakceptowaniem narracji o antropocenie a utrzymywaniem przekonania o tym, że nigdy nie byliśmy nowocześni postawiłem tezę, że błąd Latoura polegał na nietrafnej roli, jaką przypisał biegunom natury i społeczeństwa. Stały się one bowiem punktami docelowymi, do których docierało się na końcu w wyniku procesu oczyszczania. Konsekwentnie błędne jest również utrzymywanie, że nigdy nie byliśmy nowocześni dlatego, że bieguny te lokowały się w istocie na "powierzchni", zaś głębokie przekształcenia - translacje czy też hybrydyzacje były ontologicznie "płaskie”, wytwarzając sieci materialnie zróżnicowane, których kluczową cechą była stabilność.

Poniżej chciałbym zaproponować takie przepracowanie Latourowego myślenia, które modyfikując ów schemat umożliwi odrzucenie tezy o tym, że nigdy nie byliśmy nowocześni oraz pozwoli uruchomić ruch krytyczny. Ciekawe jest to, że choć argumentację w znacznej mierze opieram na krytycznym przekształcaniu, czy wręcz odrzucaniu tez Latoura, to przy pewnej interpretacji można utrzymywać, że realizuję tutaj ducha ANT czy pierwotnych intuicji Latourowskich, podążając za ich odczytaniem zaproponowanym przez Andrzeja W. Nowaka:

Polega ona [metoda ontologiczna z Irreductions - przyp. K.A.] na proceduralnym, metodologicznym zawieszeniu aktualnych relacji przyczynowo-skutkowych, stanów rzeczywistości, a następnie przy pomocy drobiazgowej pracy empirycznej (opartej o "gęsty opis", radykalną metodę etnograficzną) prześledzeniu, w jaki sposób doszło do redukcji świata do takiej postaci, z jaką aktualnie obcujemy. Program Latoura, pomimo pozornej nowości, jest ontologiczną wersją Husserlowskiej epoche. U wczesnego Husserla epoche oznaczało „wstrzymanie”, „zawieszenie” sądów sensotwórczych w obrębie pracy umysłu. ${ }^{51}$

Tak ogólne rozpoznanie mówi tyle, że istotą ANT (oraz irredukcji, czy „nieredukcji",jak pisze Nowak) nie jest taka akurat droga, jaką Latour przechodzi na swoim schemacie nowoczesności - ruch pierwszy, translacje; ruch drugi, oczyszczanie. Chodzi jedynie o ogólne zainteresowanie procesem przejścia od jakiegoś stanu wyjściowego danego układu do jego redukcji do określonego

51 A.W. Nowak Ciężar wyboru, złożoność świata i jej redukcja. Gra w Go/Weiqi jako praktykowanie "metafizyki empirycznej", „Avant" 2017 Vol. VIII, nr 3, s. 125-126. 
porządku. Rozwińmy nieco tę tezę pozostając przy przykładach z gier, którymi posługuje się Nowak.

W swojej Wyobraźni ontologicznej analizuje on w rozbudowany sposób, idąc zresztą w ślady Latoura, a jeszcze wcześniej Deleuze'a i Guattariego, grę w go $^{52}$ lub, jak zaznacza w późniejszym od książki artykule go/weiqi ${ }^{53}$, podkreślając jej chiński rodowód, jako matrycę dla myślenia o płaskiej ontologii, przeciwstawiając ją szachom. Te ostatnie byłyby z kolei świetnym modelem dla ontologii np. Arystotelesa ${ }^{54}$. Ujmując rzecz lapidarnie, różnica wygląda następująco: szachy to gra, w której każdy z uczestniczących pionków ma predefiniowane, "wewnętrzne" własności (esencje), które realizują się w świecie o również określonych właściwościach (tradycyjna szachownica). W grze chodzi o to, aby wraz z upływem czasu, w „zewnętrznym” świecie rozwijać optymalne konfiguracje tych wewnętrznych własności. Z kolei w go/weiqi każdy kamień jest identyczny, jest tylko czymś, co zajmuje miejsce. Jego rola oraz wytwarzające się struktury w całości odbywają się „na zewnątrz”. Nie ma tu realizowania przedustawnych esencji w określonych warunkach, jak w szachach, a jedynie przekształcające się struktury, kamienie uzyskują swe lokalnie określone cechy właśnie jako części tych struktur.

Na pierwszy rzut oka obie gry dobrze pasują jako modele dla Latourowego schematu Nowoczesności: go/weiqi opisuje sytuację dolnej części schematu, czyli procesów translacji, które wytwarzają tymczasowe, lokalne porządki-sieci, zaś szachy ze swoim dookreśleniem dobrze oddają górną część schematu, na której znajdują się bieguny natury i kultury z jasno i stabilnie określonymi cechami każdego z nich. Twierdzę, że powinniśmy jednak wziąć pod uwagę jeszcze trzeci poziom tych procesów i w pewnym sensie odwrócić kolejność rozpatrywania tego schematu w stosunku do Latoura tak, by uzyskać coś w rodzaju schematu z ryc. 2.

Ontologia go/weiqi dobrze opisuje poziom translacji, czyli najniższą część schematu, ale jednocześnie jej założenia pozostają jedynie hipotetycznymi wskazówkami heurystycznymi. W toku proponowanej przez ANT analizy empirycznej („empirycznej metafizyki”) możemy śledzić translacje, ale nigdy nie schodzimy do poziomu rudymentarnych kamieni z gry. Przywołajmy

A.W. Nowak Wyobraźnia ontologiczna. Filozoficzna (re)konstrukcja fronetycznych nauk społecznych, Wydawnictwo Naukowe UAM, Wydawnictwo Instytutu Badań Literackich PAN, Warszawa 2016, s. 268-284. 
przykład. W znanym fragmencie książki Nadzieja Pandory poświęconym krążącej referencji ${ }^{55}$, który wielokrotnie omawiałem ${ }^{56}$, Latour opisuje badania puszczy amazońskiej prowadzone przez grupkę uczonych. Wędruje on z nimi, analizując kolejne przejścia na drodze od „kawałka rzeczywistości” do końcowego raportu naukowego poprzez szereg kroków. Mamy więc ciąg ruchów w grze hybrydyzacji, gdzie ziemia i drzewa łączą się z przymocowanymi do nich tabliczkami opatrzonymi numerami czy nałożoną na nie abstrakcyjną siatką współrzędnych, walizka łączy się z próbkami gleby umieszczonymi w opisanych plastikowych woreczkach itd. Zawsze jednak "gra” jest rozgrywana przez gotowe, zróżnicowane elementy-aktorów. Walizkę (pedokomparator) można połączyć z próbkami gleby i woreczkami właśnie dlatego, że są od siebie różne. Możemy więc zgodnie z sugestią zawartą w go/weiqi śledzić wytwarzanie się i przekształcanie rozmaitych struktur, ale nie wydobędziemy z nich pojedynczych kamieni. Jednocześnie jasne jest, że zachodzi jakiegoś rodzaju proces „manipulowania” esencjami, że są one wykształcane na tym poziomie, ale jako esencje charakteryzujące całe sieci.

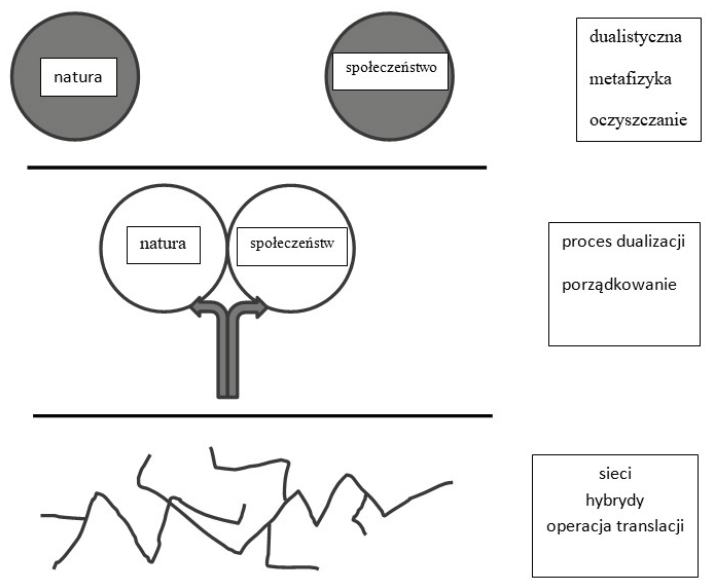

Ryc. 2. Skorygowany model Latoura przedstawiający relację między płaską ontologią sieci a ustabilizowaną dualistyczną ontologią natury i społeczeństwa. Pomiędzy nimi znajduje się strefa praktyk porządkujących, pełniących funkcję warunków możliwości dla procesów hybrydyzacji.

55 B. Latour Nadzieja Pandory. Eseje o rzeczywistości w studiach nad nauką, przeł. K. Abriszewski i in., Wydawnictwo Naukowe UMK, Toruń 2013, s. 55-112.

56 Np. w: K. Abriszewski Poznanie, zbiorowość, polityka. Analiza teorii aktora-sieci Bruno Latoura, Universitas, Kraków 2008, s. 25-51. 
Z drugiej strony do górnej części schematu możemy przyłożyć model szachów z ustabilizowanymi kategoriami ontologicznymi - esencjami. Gdyby wrócić do naszego przykładu, to będzie to moment, gdy po uzyskaniu wyników z badań, wiemy, które procesy wchodzące w grę w sytuacji rozrostu lub kurczenia się lasów są dziełem człowieka (np. wycinki), a które mają charakter naturalny (np. ekspansja nowych gatunków). W tym miejscu, dzięki takiemu porządkowi, wiemy, co robić dalej, jakich innych naukowców skierować do dalszych badań, na jakich wydziałach prezentować wyniki studentom. Słowem, tutaj "gramy" już przedustawnymi esencjami, których optymalny układ staramy się zrealizować w czasie.

Pozostaje jednak jeszcze poziom środkowy, który z braku lepszej metafory określiłbym jako „struganie szachów z pionów do go/weiqi”. Tutaj zachodziłoby porządkowanie, czyli zamienianie hybryd na względnie ustabilizowany porządek, który wprost nazwałbym „porządkiem symbolicznym” czy też „uniwersum symbolicznym”. Na pozór tylko w niewielkim stopniu poszerzam to, co Latour ujmuje na oryginalnym schemacie w procesie oczyszczania. Różnica zasadnicza jest jednak taka, że o ile dwupiętrowy model Latoura prowadzi go do tezy, że nigdy nie byliśmy nowocześni, gdyż „dół” nowoczesny nie jest (w sensie wielkiego podziału), a góra jest w ostatecznym rozrachunku nieistotna, to w proponowanej tutaj wersji jesteśmy nowocześni, właśnie dlatego, że kluczowe procesy modernizacji zachodzą na piętrze środkowym. Każda kultura (zbiorowość) operuje na hybrydach (dolne piętro), podobnie jak każda stwarza jakieś uniwersum symboliczne (górne piętro), ale odmienność tego ostatniego w kulturze nowoczesnej realizuje się w szeregu ruchów, które porządkują procesy translacji odbywające się na dole tak, aby przykrawać je do górnego porządku symbolicznego.

Świetnym, znanym w literaturze, przykładem są Foucaultowskie opisy żołnierzy z Nadzorować i karać. Żołnierz przednowoczesny jest opisany jako zasadniczo już ukształtowany ${ }^{57}$. Dla odmiany żołnierz nowoczesny jest surowym, materiałem dostarczonym przez „naturę”, który dopiero będzie podlegać odpowiedniemu kształtowaniu ${ }^{58}$. Łatwo tutaj wskazać wszystkie

57 Foucault tak go przedstawia: „Oto idealny obraz żołnierza tak jak opisywano go jeszcze na początku XVII wieku. Żołnierza przede wszystkim widać z daleka; jest nośnikiem znaków - naturalnych znaków energii i odwagi, ale również znaków dumy; jego ciało to herb jego siły i waleczności" - M. Foucault Nadzorowaći karać. Narodziny więzienia, przeł. T. Komendant, Aletheia - Spacja, Warszawa 1993, s. 161.

58 I ponownie Foucault: „Druga połowa XVIII wieku: żołnierz zostaje czymś, co można wyprodukować. Z nieforemnego ciasta, z nieporadnego ciała zrobiono odpowiadającą zapotrzebowa- 
trzy momenty procesu: surowy materiał - poziom hybrydyzacji człowieka i militarnej machiny; poziom gotowego żołnierza - ustalone kategorie w porządku symbolicznym, żołnierze i cywile; wreszcie pomiędzy nimi procesy porządkowania, wytwarzania żołnierza poprzez powtarzalne musztrowanie, szkolenie, weryfikowanie, ćwiczenie, egzaminowanie, awansowanie etc. I tutaj znajdujemy kluczowe mechanizmy modernizacyjne - w nowych formach porządkowania toczących się na skalę wcześniej niespotykaną.

Możemy teraz zapytać o pośredni wymiar z przykładu amazońskiego. Skoro śledzona przez Latoura krążąca referencja odbywa się na „najniższym poziomie" hybrydyzacji, zaś docelowo mamy uporządkowanie w postaci naturalnego lasu, ludzkiej ekspertyzy etc., to gdzie znajduje się etap pośredni? Na etapie pośrednim działają wszystkie te siły, procesy i aktorzy, którzy operują składowymi z pierwszego, najniższego poziomu. Skoro Latour patrzy na ręce ekipie badawczej, to tutaj - na poziomie środkowym - można zapytać: kto wysłał tę ekipę? W jakich celach? Skąd zaczerpnięto środki na wyprawę? Kto skorzysta na jej wynikach? Gdzie pojawi się publikacja i w jakim porządku ekonomicznym (prywatny wydawca, darmowe dane publiczne)? Innymi słowy, każdy z uczestniczących aktorów w analizowanym przez Latoura procesie konstruowania krążącej referencji ma swój kontekst konstruowania. To jest moment porządkowania: gdzie trafią wyniki?, co się będzie działo z uczestnikami?, co się stanie z puszczą?, kto będzie o tym decydował? - to są pytania, które również można postawić.

Właśnie tego rodzaju pytania mają charakter krytyczny. Latour nie odkrywa relacji władzy, ponieważ studiując swoje lokalne przepływy i połączenia, nie stawia starego, Kantowskiego pytania krytycznego o warunki możliwości, już jednak nie w duchu królewieckiego filozofa, czyli o ogólne, niezmienne metafizyczne warunki, ale w duchu filozofa, z którego Latour dużo czerpał, to jest z Gilles'a Deleuze'a. Chodzi o jego warunki możliwości, ale pojmowane empirycznie, jako ulokowane w sferze immanencji ${ }^{59}$.

niom maszynę; wytresowano, krok po kroku, zachowanie; zaplanowany przymus powoli wnika w każdą część ciała, opanowuje je, nagina całość, nadaje mu nieustanną gotowość i znajduje przedłużenie w automatyzmie nawyków" - tamże, s. 161. Swoją drogą, wątek ten otwiera ciekawą ścieżkę łączącą sposób ujęcia Nowoczesności z rolą czterech "tanich darów natury" (cheap natures), o których dużo pisze Jason W. Moore (Capitalism in the Web of Life).

59 Kwestie te bardzo dokładnie i w sposób rozbudowany omawia Michał Herer - tegoż Gilles Deleuze: struktury, maszyny, kreacje, Universitas, Kraków 2006. 
Rzecz wydaje się - mimo wszystko - całkowicie prosta. Choćby w przykładzie geologów, którym Latour poświęca tyle miejsca ${ }^{60}$. Na poziomie montowania (splatania, asemblowania) antropocenu zastanawiają się, głosują, prowadzą dalsze badania. Na poziomie pytania transcendentalnego, krytycznego, które porządkuje ich rozważania, można zastanawiać się, dzięki jakim środkom mogą siedzieć godzinami i debatować? Kto zapłacił za to, że zjechali się w jedno miejsce? Kto utrzymuje sieci komunikacyjne, dzięki którym mogli się spotkać? Których geologów i z jakich powodów nie było stać na to, by dotrzeć na to spotkanie? Wracają również wszystkie te pytania i uwagi, które pod adresem dominującej narracji antropocenowej kierują Bonneuil i Fressoz, jak np. dlaczego nie istnieje społeczna historia energii? jak do antropocenu ma się XX-wieczny przemysł wojenny? jakie są związki między zmianą klimatyczną a kulturą konsumpcji?

Powtórzmy więc jeszcze raz, jeśli dolny poziom schematu Latoura, przedstawiający translacje, hybrydyczne sieci odpowiada Nietzscheańskiemu ścieraniu się sił (oczywiście w interpretacji Deleuzjańskiej ${ }^{61}$ ), kamieniom z go/ weiqi czy też bytom, które się do siebie nie redukują z Irreductions ${ }^{62}$, to poziom środkowy oznacza empiryczne warunki możliwości, które konkretyzują i porządkują to, co dzieje się „poniżej”. Zaś już uporządkowane rezultaty pojawiają się na "górnym" piętrze modelu jako względnie ustabilizowane uniwersum, którego jedną z cech charakterystycznych może być dychotomiczny układ biegunów natury i społeczeństwa. Dla lepszego uzmysłowienia tego, co dzieje się na środkowym poziomie porządkującym, możemy podstawić w to miejsce rozmaite propozycje, które usiłowały uchwycić nowoczesność, jej narodziny i rozwój. Można więc za tradycją marksowską widzieć tu procesy utowarowienia wkraczające w coraz to nowe obszary, można za Anthonym Giddensem zwrócić uwagę na wykorzenianie lokalnych zjawisk i interakcji, skutkujące ich przekształcaniem w długie łańcuchy rozpięte na „nieokreślonych obszarach czasoprzestrzeni" ${ }^{63}$, możemy też rozpoznać tu mechanizm przesuwania granic systemowych, który tak bardzo akcentuje Jason Moore ${ }^{64}$.

60 B. Latour Facing Gaia, s. 140-147.

61 G. Deleuze Nietzsche i filozofia, przeł. B. Banasiak, Spacja, Warszawa 1993.

62

B. Latour The Pasteurization of France, trans. A. Sheridan, J. Law, Harvard University Press Cambridge MA-London 1988, s. 153-238.

63 A. Giddens Konsekwencje nowoczesności, przeł. E. Klekot, Wydawnictwo U), Kraków 2008, s. 15-21.

64 J.W. Moore Capitalism in the Web of Life. 
Toteż, odpowiadając na wyjściowe pytania, możemy jedynie posługiwać się trybem warunkowym: Latour i szerzej, ANT w wersji zasadniczej nie dają narzędzi krytycznych, odpowiedniego schematu prowadzenia dociekań. Taką moc krytyczną można jednakże uzyskać pod warunkiem rozbudowania ANT-owych narzędzi w taki sposób, jak zaproponowałem powyżej. Podkreślmy jednakże, że kierunek tej rozbudowy nie byłby szczególnie mile widziany przez Latoura, gdyż obejmowałby z konieczności ustabilizowane, ale znacznie obszerniejsze struktury wiedzy i struktury władzy, wprowadzając do gry takie pojęcia jak „,kapitalizm”, ,wyzysk strukturalny”, ,międzynarodowy osiowy podział pracy” czy „relacje centro-peryferyjne”. Z kolei pytanie o to, jak badać kulturę $\mathrm{w}$ antropocenie, czy uprawiać kulturoznawstwo antropocenowe, z jednej strony należałoby tutaj połączyć z postulatami wzmocnienia ANT o możliwości pracy krytycznej, a z drugiej podążyć ścieżką, którą w rozbudowany sposób kreśli Andrzej W. Nowak w swojej Wyobraźni ontologicz$n e j$ - rozbudowywać płaską ontologię ANT (i ujęć pokrewnych) o momenty aksjologiczne.

\section{Abstract}

\section{Krzysztof Abriszewski}

NICOLAUS COPERNICUS UNIVERSITY (TORUŃ)

Does Actor-Network Theory Offer Conceptual Tools for Ecocritisicm?

Abriszewski asks whether Bruno Latour's longtime theoretical project offers or is able to offer a viable conceptual tool for ecocriticism. By this he means any concepts and ideas for the critical analysis of social and cultural reality in the context of environmental problems. The analysis follows three paths: 1 . Latour's famous claim that we have never been modern; 2. The theoretical position elaborated in Latour's Facing Gaia; 3. A short discussion of some of Latour's recent critics. In conclusion Abriszewski suggests that Latour's concept of modernity ought to be reconstructed in order to become useful for the critical work.

\section{Keywords}

actor-network theory, criticism, anthropocene, modernity 